OPEN ACCESS

Edited by:

Jozsef Soki,

University of Szeged, Hungary

Reviewed by:

Andrew Clark,

University of Texas Southwestern

Medical Center, United States

*Correspondence:

Benjamin Lardinois

benjamin.lardinois1@gmail.com

Specialty section:

This article was submitted to Infectious Agents and Disease,

a section of the journal

Frontiers in Microbiology

Received: 14 November 2021 Accepted: 17 December 2021

Published: 23 February 2022

Citation:

Lardinois B, Belkhir L and Verroken A (2022) Helicobacter canis: A Review of Microbiological and Clinical Features.

Front. Microbiol. 12:814944. doi: 10.3389/fmicb.2021.814944

\section{Helicobacter canis: A Review of Microbiological and Clinical Features}

\author{
Benjamin Lardinois ${ }^{1 *}$, Leïla Belkhir ${ }^{2}$ and Alexia Verroken ${ }^{1}$ \\ 'Department of Microbiology, Cliniques universitaires Saint-Luc, Université catholique de Louvain, Brussels, Belgium, \\ ${ }^{2}$ Department of Internal Medicine and Infectious Diseases, Cliniques universitaires Saint-Luc, Université catholique \\ de Louvain, Brussels, Belgium
}

Helicobacter canis, an enterohepatic Helicobacter, has proven its role in human diseases and has been rediscussed in recent years as its zoonotic potential is increasingly described. Routine microbiological detection of this pathogen is a difficult task as its culture may fail due to fastidious growth. It is therefore supposed that many clinical laboratories under-recognize $H$. canis infections. A review of all clinical and microbiological literature currently available from previous relevant $H$. canis human clinical cases, mainly bacteremia, added with a clinical case observed at the Cliniques universitaires Saint-Luc, was performed. Clinical features of $H$. canis reports show the presence of underlying clinical conditions in $89 \%$ of the cases, bacteremia in $83 \%$, associated fever in 58\%, and recent close contact with pets in $83 \%$, especially dogs. The observed microbiological trends from 10 cases of bacteremia were a median of 4 days until positive blood culture bottle detection, subcultures showing a thin layer of small colonies under microaerophilic atmosphere at $35-42^{\circ} \mathrm{C}$ after $3-4$ days of growth, and an identification requiring $16 \mathrm{~S}$ rRNA sequencing given the difficulties observed with MALDI-TOF MS. Low MICs were observed for penicillins, amoxicillin/clavulanic acid, carbapenems, and metronidazole in opposition to high MICs for ciprofloxacin. A frequent association of $\mathrm{H}$. canis and bacteremia in immunocompromised patients with recurrent fever in contact with pets, especially dogs, was identified. Considering the fastidious growing capacities, final identification from blood cultures may not be expected before 7 days. Intravenous ceftriaxone, oral doxycycline, or metronidazole has been suggested as efficient therapeutic choices.

Keywords: Helicobacter canis, bacteriology, bacteremia, susceptibility testing, mini-review, clinical features

\section{INTRODUCTION}

Initially discovered by Stanley et al. (1993) from the feces of dogs, Helicobacter canis has been rediscussed in recent years as its zoonotic potential is increasingly described. Several Helicobacter species find their reservoirs in animals even for H. pylori (Momtaz et al., 2014). Non-pylori Helicobacter species and especially enterohepatic Helicobacter including H. canis have proven their role in human diseases (Ménard et al., 2014; Liu et al., 2015). Swennes et al. (2014) identified sheep as a potential reservoir, and Sabry et al. (2016) reported an indisputable zoonotic transmission by comparing $H$. canis sequences from humans and sheep contacts. Interestingly, nine clinical cases with $H$. canis bacteremia including the current one reported close contacts with cats or dogs 
(Gerrard et al., 2001; Leemann et al., 2006; Prag et al., 2007; Alon et al., 2010; Abidi et al., 2013; van der Vusse et al., 2014; Shakir et al., 2017; Mihevc et al., 2021). Seven of them, including ours, concerned patients with underlying conditions (Gerrard et al., 2001; Alon et al., 2010; Abidi et al., 2013; van der Vusse et al., 2014; Shakir et al., 2017; Mihevc et al., 2021).

Detection of $H$. canis by a microbiology laboratory is a difficult task under routine conditions as culturing of Helicobacter species may fail due to fastidious growth. Therefore, many clinical laboratories may under-recognize this germ, and the prevalence of this organism might hereby be underestimated. Microbiologists as well as clinicians should keep in mind its potential for clinical involvement. Only laboratories with gene sequencing capability are able to reliably identify the pathogen from clinical specimens. An optimal communication between microbiologists and physicians is therefore crucial.

To our knowledge, three cases have investigated the antimicrobial susceptibility of $H$. canis strains (Leemann et al., 2006; Prag et al., 2007; Mihevc et al., 2021). Here we described a case of $H$. canis bacteremia in an immunocompromised woman suffering from end-stage renal disease with a possible zoonotic transmission. We also summarized data from previous relevant $H$. canis human clinical cases reviewing the pathogen, its susceptibility profile, and the frame of infectious diseases caused.

\section{CASE STUDY}

A 55-year-old woman initially consulted a nephrologist for renal transplantation follow-up. She had undergone a renal transplant 13 years earlier after being diagnosed with an autosomal dominant polycystic kidney disease but the graft had become gradually dysfunctional. Additional comorbidities included secondary hyperparathyroiditis and moderate anemia as well as a long-standing splenectomy. At the time of consultation, she described flu-like symptoms and fatigue in addition to increasing diarrhea. The dosage of mycophenolate mofetil (MMF), part of her immunosuppressive therapy, was therefore temporarily reduced. Interestingly, she had presented several episodes of shivers few days earlier but had not measured body temperature at home. Clinical examination revealed a traumatic pretibial wound with an associated slight edema. However, no cellulitis was observed despite a fragile skin under cortisone conditions.

Additional testing included blood culture sampling composed of two sets of a BACTEC Plus Aerobic/F culture vial and a BACTEC Plus Anaerobic/F culture vial (Becton Dickinson Diagnostic Systems, Sparks, MD, United States) and incubated in a Bactec 9240 instrument (Becton Dickinson). Bacterial growth was detected in a single aerobic bottle 3 days and $4 \mathrm{~h}$ following incubation. Gram revealed Gram-negative, spiral-shaped microorganisms. No acridine orange stain was performed. The positive bottle was subcultured on Columbia 5\% sheep blood agar in a $5 \% \mathrm{CO}_{2}$ atmosphere at $35^{\circ} \mathrm{C}$ according to routine laboratory workflow. As no growth was observed, additional subcultures were initiated on a horse blood enriched with cofactor $\mathrm{V}$ and $\mathrm{X}$ agar, a Gram-negative selective and differentiating medium, a 5\% horse blood Brucella agar, and a Campylobacter medium supplemented with activated charcoal, all incubated at $35^{\circ} \mathrm{C}$ in a $7.2 \% \quad \mathrm{CO}_{2}$ and $6 \% \quad \mathrm{O}_{2}$ atmosphere (equals microaerophilic conditions). These subsequent subcultures all successfully recovered colonies within 3-5 days. Optimal growth was obtained on Brucella 5\% sheep blood agar in microaerophilic conditions showing a thin layer of colonies with a cloudlike appearance after 3 days (see Supplementary Figure 1). The micro-organism was oxydase positive. Unfortunately, no identification was possible using matrix-assisted laser desorption ionization-time of flight mass spectrometry (MALDI-TOF MS) (Microflex LT; Bruker Daltonics, Bremen, Germany).

Ultimately, identification was realized by partial sequencing of 1458 base pairs of the $16 \mathrm{~S}$ ribosomal ribonucleic acid (rRNA) gene of which 1,213 base pairs were analyzable on a Genetic Analyzer ABI 3730XL (Applied Biosystems; Invitrogen Life Technologies, Carlsbad, CA, United States), with the BigDye Terminator kit (Applied Biosystems) using a laboratorydeveloped method (Wauters et al., 2003). It revealed 99.9\% identity correspondence representing Helicobacter canis $16 \mathrm{~S}$ rRNA gene sequences after Basic Local Alignment Search Tool (BLAST) analysis of the consensus. The nucleotide sequence was submitted to GenBank and obtained the accession number AY631946.

Antimicrobial susceptibility testing (AST) using E-tests (bioMérieux, Marcy-l'Etoile, France) was performed for minimum inhibitory concentration (MIC) determination. The E-tests were placed on three McFarland inoculum Brucella agar plates and incubated in microaerophilic conditions for $72 \mathrm{~h}$ according to the manufacturer's recommendations (see Supplementary Figure 2). Microbiological investigations and MICs reported to the physicians are summarized in Supplementary Table 1. H. pylori-related EUCAST 2021 breakpoints were used for rifampicin, metronidazole, and tetracycline since there were no species-specific breakpoints or other recommendations for these antibiotics. PK-PD EUCAST 2021 breakpoints were used for the other antibiotics (The European Committee on Antimicrobial Susceptibility Testing, 2021). No breakpoints were considered for clindamycin MIC.

Interestingly, a slight increase of C-reactive protein the day of venipuncture was noticed compared to a previous blood test 2 weeks earlier. The white blood cells were within the reference range $(\mathrm{RR})\left(8.8 \times 10^{3}\right.$ cells $/ \mu \mathrm{l} ; \mathrm{RR} 4.0-10.0 \times 10^{3}$ cells $\left./ \mu \mathrm{l}\right)$. Total IgG were slightly below reference range $(6.8 \mathrm{~g} / \mathrm{L}$; RR 7.0$16.0 \mathrm{~g} / \mathrm{L})$. Other blood test results realized during follow-up showed no other acute abnormalities. Urine analysis reported a slight increase of white blood cells ( 8 cells/field; RR $<5$ cells/field) and moderate bacteriuria. Urine culture showed a mixed contamination flora and stool cultures did not grow with any enteropathogenic germ despite the use of a Campylobacter medium supplemented with activated charcoal and a blood-based Campylobacter medium.

The patient was admitted to the hospital 20 days after her follow-up appointment in order to treat the bacteremia. Four sets of blood cultures were sampled with an extended 14-day incubation time, yet all were reported negative. A swab from the persistent tibial wound was cultured according to identical 
TABLE 1 | Previous and current microbiological investigations of $H$. canis isolated from blood cultures.

\begin{tabular}{|c|c|c|c|c|c|c|c|c|c|c|c|}
\hline Author & $\begin{array}{l}\text { Detection in } \\
\text { blood bottle }\end{array}$ & $\begin{array}{l}\text { Time to } \\
\text { detection }\end{array}$ & $\begin{array}{l}\text { Microscopic } \\
\text { examination }\end{array}$ & Positive subcultures & $\begin{array}{l}\text { Time to } \\
\text { grow }\end{array}$ & Colonies aspect & Identification & \multicolumn{2}{|c|}{ AST } & Treatment & Outcome \\
\hline $\begin{array}{l}\text { Lardinois et al. } \\
\text { (Current report) }\end{array}$ & $\begin{array}{c}1 \text { out of } 4(1 \\
\text { AE) }\end{array}$ & 3 days & $\begin{array}{l}\text { Gram negative and } \\
\text { spiral-shaped rods }\end{array}$ & $\begin{array}{l}\text { Columbia, chocolate, } \\
\text { MacConkey and } \\
\text { Karmali agar } \\
\text { Best with Brucella } \\
\text { Microaerophilic } \\
\text { atmosphere } 35^{\circ} \mathrm{C}\end{array}$ & $3-5$ days & $\begin{array}{l}\text { Thin layer with a } \\
\text { cloud-like appearance } \\
\text { in the medium }\end{array}$ & $\begin{array}{l}\text { 16S rRNA } \\
\text { sequencing on } \\
\text { subculture }\end{array}$ & $\begin{aligned} & \text { MICs by } E-t e \\
& A M=0.064 \\
& A V=0.047 \\
& C R O=0.075 \\
& M P<0.002 \\
& M Z<0.016(S)\end{aligned}$ & $\begin{array}{l}\text { ts }(\mu \mathrm{g} / \mathrm{m})^{*}: \\
\mathrm{CM}=2 \\
\mathrm{Cl}>32 \\
\mathrm{TC}<0.016(\mathrm{~S}) \\
\mathrm{Rl}<0.002(\mathrm{~S})\end{array}$ & $\begin{array}{l}\text { Ceftriaxone i.v. for } \\
6 \text { weeks. }\end{array}$ & $\begin{array}{l}\text { Bacteriological } \\
\text { and clinical } \\
\text { cure }\end{array}$ \\
\hline $\begin{array}{l}\text { Mihevc et al., } \\
2021\end{array}$ & 2 out of 4 (2AE) & 5 days & $\begin{array}{l}\text { Gram negative spiral } \\
\text { rods }\end{array}$ & $\begin{array}{l}\text { Columbia sheep agar } \\
\text { Microaerophilic } \\
\text { atmosphere } 37^{\circ} \mathrm{C} \\
\text { Blood agar, Columbia } \\
\text { agar } 5 \% \text { horse blood, } \\
\text { Columbia agar } 5 \% \\
\text { sheep blood, Brucella } \\
\text { agar } \\
\text { Microaerophilic } \\
\text { atmosphere } 37 \text { and } \\
42^{\circ} \mathrm{C}\end{array}$ & $\begin{array}{l}2 \text { days } \\
3-4 \text { days }\end{array}$ & $\begin{array}{l}\text { Shiny translucent } \\
\text { colonies of round or } \\
\text { irregular shape }\end{array}$ & $\begin{array}{l}\text { 16S rRNA } \\
\text { sequencing and } \\
\text { MALDI-TOF MS } \\
\text { on subculture }\end{array}$ & $\begin{aligned} \text { MICS by E-t } & \\
\mathrm{A} C & =0.016(\mathrm{~S}) \\
\mathrm{CTX} & =0.125(\mathrm{~S}) \\
\mathrm{CRO} & =0.25(\mathrm{~S})\end{aligned}$ & $\begin{array}{l}\text { sts }(\mu \mathrm{g} / \mathrm{mll}) \\
\mathrm{GM}=0.064 \\
\mathrm{MP}=0.25\end{array}$ & $\begin{array}{l}\text { Ceftriaxone i.v. and } \\
\text { peroral doxycycline for } \\
14 \text { days }\end{array}$ & $\begin{array}{l}\text { Bacteriological } \\
\text { and clinical } \\
\text { cure }\end{array}$ \\
\hline $\begin{array}{l}\text { Gutiérrez-Arroyo } \\
\text { et al., } 2017\end{array}$ & $\begin{array}{c}2 \text { out of } 2 \text { (2 } \\
\text { Peds) }\end{array}$ & 6 days & $\begin{array}{l}\text { Thin, curved } \\
\text { Gram-negative bacilli }\end{array}$ & $\begin{array}{l}\text { H. pylori selective } \\
\text { supplement (Dent) } \\
\text { blood base agar } \\
\text { Microaerophilic } \\
\text { atmosphere } 37 \text { and } \\
42^{\circ} \mathrm{C}\end{array}$ & 7 days & Not reported & $\begin{array}{l}16 S \text { rRNA } \\
\text { sequencing on } \\
\text { subculture }\end{array}$ & Not re & orted & $\begin{array}{l}\text { Cefotaxime i.v. and } \\
\text { Metronidazole I.V. }\end{array}$ & Brain death \\
\hline $\begin{array}{l}\text { Shakir et al., } \\
2017\end{array}$ & $\begin{array}{c}4 \text { out of } 4(4 \\
\text { AE) }\end{array}$ & 5 days & $\begin{array}{c}\text { Small, curved } \\
\text { Gram-negative rods }\end{array}$ & $\begin{array}{l}\text { Sheep blood agar } \\
\text { Microaerophilic } \\
\text { atmosphere } 35 \text { and } \\
42^{\circ} \mathrm{C}\end{array}$ & 3 days & Small and tan & $\begin{array}{l}16 \mathrm{~S} \text { rRNA } \\
\text { sequencing on } \\
\text { subculture }\end{array}$ & Not pe & ormed & $\begin{array}{l}\text { Doxycycline for } 7 \text { days } \\
\text { then peroral } \\
\text { Amoxicillin- } \\
\text { clavulanate for } \\
8 \text { weeks }\end{array}$ & $\begin{array}{l}\text { Bacteriological } \\
\text { and clinical } \\
\text { cure }\end{array}$ \\
\hline $\begin{array}{l}\text { van der Vusse } \\
\text { et al., } 2014\end{array}$ & $\begin{array}{c}1 \text { out of } 6 \text { (1 } \\
\text { ANA) }\end{array}$ & 3 days & $\begin{array}{l}\text { Unusual, slightly } \\
\text { curved, gram negative } \\
\text { rods }\end{array}$ & $\begin{array}{l}\text { Failed to grow } \\
\text { Aerobic and } \\
\text { anaerobic atmosphere }\end{array}$ & Not reported & Not reported & $\begin{array}{l}\text { 16S rRNA } \\
\text { sequencing on } \\
\text { blood bottle }\end{array}$ & Not pe & ormed & $\begin{array}{l}\text { Cefuroxime for } 3 \text { days } \\
\text { then Ciprofloxacin for } \\
10 \text { days }\end{array}$ & $\begin{array}{l}\text { Bacteriological } \\
\text { and clinical } \\
\text { cure }\end{array}$ \\
\hline Abidi et al., 2013 & $\begin{array}{c}4 \text { bottles out of } \\
6(4 \mathrm{AE})\end{array}$ & 4 days & $\begin{array}{l}\text { Rod-like organisms } \\
\text { after acridine orange } \\
\text { stain } \\
\text { Gram-negative bacilli }\end{array}$ & $\begin{array}{l}\text { Chocolate blood agar } \\
\text { Microaerophilic } 37 \\
\text { and } 42^{\circ} \mathrm{C} \text { (optimal) }\end{array}$ & $2-3$ days & Thin and oily film & $\begin{array}{l}\text { 16S rRNA } \\
\text { sequencing and } \\
\text { MALDI-TOF MS } \\
\text { on subculture }\end{array}$ & Not pe & ormed & $\begin{array}{l}\text { Oral doxycycline for } \\
6 \text { weeks and } \\
\text { ceftriaxone i.v. for } \\
2 \text { weeks }\end{array}$ & $\begin{array}{l}\text { Bacteriological } \\
\text { and clinical } \\
\text { cure }\end{array}$ \\
\hline Alon et al., 2010 & $\begin{array}{l}\text { 1st episode: } 2 \\
\text { out of } 4 \text { (2 AE) } \\
\text { 2nd episode: } 3 \\
\text { out of } 4 \text { (2 AE } \\
\text { and } 1 \text { ANA) }\end{array}$ & $\begin{array}{l}2 \text { days } \\
3 \text { days }\end{array}$ & $\begin{array}{l}\text { Unusual, spiral } \\
\text { Gram-negative rods }\end{array}$ & $\begin{array}{l}\text { Failed to grow } \\
\text { Aerobic and } \\
\text { anaerobic atmosphere }\end{array}$ & Not reported & Not reported & $\begin{array}{l}\text { 16S rRNA } \\
\text { sequencing on } \\
\text { blood bottle. }\end{array}$ & Not pe & ormed & $\begin{array}{l}\text { Cefuroxime for } 3 \text { days } \\
\text { then peroral } \\
\text { amoxicillin, } \\
\text { omeprazole, and } \\
\text { clarithromycin for } \\
4 \text { weeks }\end{array}$ & $\begin{array}{l}\text { Bacteriological } \\
\text { and clinical } \\
\text { cure }\end{array}$ \\
\hline
\end{tabular}


TABLE 1 | (Continued)

\begin{tabular}{|c|c|c|c|c|c|c|c|c|c|c|c|}
\hline Author & $\begin{array}{l}\text { Detection in } \\
\text { blood bottle }\end{array}$ & $\begin{array}{c}\text { Time to } \\
\text { detection }\end{array}$ & $\begin{array}{l}\text { Microscopic } \\
\text { examination }\end{array}$ & Positive subcultures & $\begin{array}{l}\text { Time to } \\
\text { grow }\end{array}$ & Colonies aspect & Identification & \multicolumn{2}{|c|}{ AST } & Treatment & Outcome \\
\hline Prag et al., 2007 & $\begin{array}{l}1 \text { pediatric } \\
\text { bottle }\end{array}$ & 5 days & $\begin{array}{l}\text { Small, Gram-negative } \\
\text { spiral rods, 2-3 mm } \\
\text { long }\end{array}$ & $\begin{array}{l}5 \% \text { sheep blood, } \\
\text { chocolate and } \\
\text { Brucella agar. Best } \\
\text { with } 5 \% \text { horse blood } \\
\text { agar plates with yeast } \\
\text { extract } \\
\text { Aerobic, anaerobic } \\
\text { and microaerophilic } \\
\text { atmosphere } 37 \text { and } \\
42^{\circ} \mathrm{C}\end{array}$ & 4 days & Very small & $\begin{array}{l}16 \mathrm{~S} \text { rRNA } \\
\text { sequencing on } \\
\text { subculture }\end{array}$ & \multicolumn{2}{|c|}{$\begin{array}{l}\text { Cephalothin } 30 \mu \mathrm{g} \text { (R) } \\
\text { Acid nalidixic } 30 \mu \mathrm{g}(\mathrm{S})\end{array}$} & $\begin{array}{l}\text { Ampicillin and } \\
\text { gentamicin i.v. then } \\
\text { peroral mecillinam for } \\
10 \text { days }\end{array}$ & $\begin{array}{l}\text { Clinical } \\
\text { recurrence }\end{array}$ \\
\hline $\begin{array}{l}\text { Leemann et al., } \\
2006\end{array}$ & $\begin{array}{c}1 \text { out of } 4(1 \\
\text { AE) }\end{array}$ & 3 days & $\begin{array}{l}\text { Spiral-shaped } \\
\text { bacteria on acridine } \\
\text { orange staining }\end{array}$ & $\begin{array}{l}\text { Brucella agar } \\
\text { supplemented with } \\
\text { hemin, vitamin } \mathrm{K} 1 \text {, } \\
\text { cysteine, and } 5 \% \\
\text { sheep blood } \\
\text { Anaerobic and } \\
\text { microaerophilic } \\
\text { atmosphere } 37^{\circ} \mathrm{C}\end{array}$ & $\begin{array}{c}\text { Not } \\
\text { mentioned }\end{array}$ & Small and grayish & $\begin{array}{l}16 \mathrm{~S} \text { rRNA } \\
\text { sequencing on } \\
\text { subculture }\end{array}$ & \multicolumn{2}{|c|}{\begin{tabular}{ll}
\multicolumn{2}{c}{ MICs by E-tests: } \\
Amoxicillin $=0.38$ & $\mathrm{IMI}=0.047$ \\
$\mathrm{~A} / \mathrm{C}=0.094(\mathrm{~S})$ & $\mathrm{MZ}=0.064$ \\
$\mathrm{CRO}=0.75(\mathrm{~S})$ & $\mathrm{CM}=0.094$
\end{tabular}} & $\begin{array}{l}\text { Amoxicillin- } \\
\text { clavulanate for } \\
10 \text { days then } \\
\text { ceftriaxone i.v. } \\
\text { for } 2 \text { weeks }\end{array}$ & $\begin{array}{l}\text { Clinical } \\
\text { recurrence then } \\
\text { bacteriological } \\
\text { and clinical } \\
\text { cure }\end{array}$ \\
\hline $\begin{array}{l}\text { Gerrard et al., } \\
2001\end{array}$ & $\begin{array}{c}2 \text { out of } 10(2 \\
A E)\end{array}$ & Not mentioned & $\begin{array}{l}\text { Gram-negative spiral } \\
\text { organism }\end{array}$ & $\begin{array}{l}\text { Tryptic soy agar with } \\
5 \% \text { sheep blood and } \\
\text { chocolate agar. } \\
\text { Aerobic and } \\
\text { anaerobic atmosphere } \\
35^{\circ} \mathrm{C}\end{array}$ & 3-4 days & Not mentioned & $\begin{array}{l}16 S \text { rRNA } \\
\text { sequencing on } \\
\text { subculture }\end{array}$ & \multicolumn{2}{|c|}{ Not performed } & $\begin{array}{l}\text { Ampicillin i.v, } \\
\text { Gentamicin i.v. and } \\
\text { Ciprofloxacin then } \\
\text { doxycycline and } \\
\text { Metronidazole for } \\
5 \text { months }\end{array}$ & $\begin{array}{l}\text { Clinical } \\
\text { recurrence then } \\
\text { bacteriological } \\
\text { and clinical } \\
\text { cure }\end{array}$ \\
\hline Trends & $\begin{array}{c}50 \% \text { of } \\
\text { aerobic blood } \\
\text { bottles }\end{array}$ & 4 days & $\begin{array}{c}\text { Gram-negative } \\
\text { spiral shaped rods }\end{array}$ & $\begin{array}{l}\text { Enriched } \\
\text { non-selective media } \\
\text { Microaerophilic } \\
\text { atmosphere } \\
35^{\circ} \mathrm{C}-42^{\circ} \mathrm{C}\end{array}$ & 3-4 days & $\begin{array}{l}\text { Thin layer of small } \\
\text { colonies }\end{array}$ & $\begin{array}{c}16 \mathrm{~S} \text { rRNA } \\
\text { sequencing }\end{array}$ & \multicolumn{2}{|c|}{ Determine MICs if possible } & No guidelines & Favorable \\
\hline
\end{tabular}

AE, aerobic; ANC, amoxicillin-clavulanate; AM, ampicillin; ANA, anaerobic; AST, antimicrobial susceptibility testing; Cl, ciprofloxacin; CM, clindamycin; CTX, cefotaxime; CRO, ceftriaxone; GM, gentamicin; IMI, imipenem; I.V., intravenous; MALDI-TOF, matrix-assisted laser desorption ionization-time of flight mass spectrometry; MIC, minimal inhibitory concentration; MP, meropenem; MZ, metronidazole; P/T, piperacillin-tazobactam; $R$ resistant; rRNA, ribosomal ribonucleic acid; RI, rifampicin; S, susceptible; TC, tetracycline. *See Supplementary Table 1. 
conditions as described for the blood culture bottles, but $H$. canis remained undetected. Similarly, we failed to detect the strain in the patient's stool. A bacteriological culture was also realized on the patient's dog's stool; however, it did not reveal the germ. Additional urine and stool cultures showed results with no clinical relevance during the 2 weeks of hospitalization.

The patient received an intravenous ceftriaxone $2 \mathrm{~g} / \mathrm{day}$ antibiotic therapy for 6 weeks.

She was eventually cured and continued to be monitored every 2 weeks for her chronic kidney disease.

\section{DISCUSSION}

This review aimed at identifying the common features of previous and current $H$. canis bacteremia to assist clinicians in the management of these patients. Two case reports without bacteremia are also discussed. To the best of our knowledge, 12 human clinical cases including the current one have already been reported about $H$. canis, but recommendations are scarce. Initially discovered in 1993 from the feces of healthy or diarrheic dogs (Stanley et al., 1993), then clinically reported the same year in a boy with gastroenteritis (Burnens et al., 1993), this enterohepatic pathogen has proven its involvement over the recent years in bacteremia in patients with and without co-morbidities.

Surprisingly, the typical reservoir of this species is not fully understood as no epidemiologic studies have been performed (van der Vusse et al., 2014). However, several studies identified $H$. canis as a dominant Helicobacter in the digestive system of both healthy and unhealthy dogs and cats (Stanley et al., 1993; Fox et al., 1996; Foley et al., 1999; Shen et al., 2001; Ekman et al., 2013; Tabrizi and Atashi, 2015; Ochoa et al., 2021b). Unlike other enterohepatic Helicobacter species, $H$. canis may induce an active host immune response as observed in an experimental model using the wax moth larvae Galleria mellonella (Ochoa et al., 2021a), supporting previous observations of infection in immunocompromised hosts. Recently, the bacteria was identified in sheep feces (Swennes et al., 2014; Sabry et al., 2016). One study proved zoonotic transmission of the germ by obtaining identical sequences of identity matrix in sheep and its animal caretaker. The contamination would have occurred by milk, animal carcass, or potentially through direct fecal-oral route (Sabry et al., 2016). Transmission of commensal Helicobacter species living in the intestines of animals is not obvious although the latter route is the most likely (Ekman et al., 2013; van der Vusse et al., 2014). Lack of urease activity, bile tolerance, and fecal source could explain a preferential digestive carriage in the lower intestinal tract (Stanley et al., 1993; Alon et al., 2010). Although possible carriage of $H$. canis in humans needs further investigations, it could explain translocation from the intestines to the bloodstream once the mucosa is damaged, either by a virus (Burnens et al., 1993) or by an immunosuppressive therapy such as MMF as cited in this report and in a previous one (Abidi et al., 2013). Interestingly, close contacts with pets mainly with dogs was reported in $83 \%$ of clinical cases including this one reinforcing the hypothesis of zoonotic transmission by a companion animal. The source of the bacteremia could not be confirmed in many cases since patients experienced skin abnormalities and/or digestive symptoms with underlying conditions that possibly contributed to the entry of the germ in the bloodstream. Our clinical case reflected this ambiguity as the immunocompromised patient had a skin wound and increasing diarrhea.

Previous and current microbiological investigations are summarized in Table 1. Although anaerobic blood bottles were reported positive in two cases (Alon et al., 2010; van der Vusse et al., 2014), aerobic blood bottles were more likely to detect $H$. canis which is in accordance with the microaerophilic atmosphere required for the germ's growth. Pediatric blood bottles enriched with yeast or meat extract with less sodium polyanetholsulfonate were also described to be suitable for the pathogen's detection (Prag et al., 2007; Gutiérrez-Arroyo et al., 2017). Interestingly, about half of the aerobic blood bottles sampled on patients' admissions were reported positive with an average time-to-detection of 4 days. This delay is within the classical 5-day blood culture incubation period applied by most clinical microbiology laboratories. Acridine orange and Gram staining described both curved- and spiral-shaped rods. Two case-reports related the fact that enterohepatic Helicobacter are difficult or even impossible to subculture (Alon et al., 2010; van der Vusse et al., 2014). The use of enriched non-selective media such as $5 \%$ sheep blood, chocolate, or Brucella agar which are commonly used in bacteriology laboratories appeared to be appropriate. On the other hand Mueller-Hinton media did not allow the growth of $H$. canis (Ochoa et al., 2019). Optimal growth was obtained under microaerophilic atmosphere at 35$42^{\circ} \mathrm{C}$ and the suspicious bacterial colonies were visible to the naked eye after an average of 3-4 day-incubation. Identification of $H$. canis was particularly difficult by standard methods considering its weak biochemical reactivity. Even MALDI-TOF MS was not suitable given the high number of identification failures in previous reports. Only two reports partially succeeded in identifying $H$. canis by this technique with a score of 1.93 and 1.88, respectively (Abidi et al., 2013; Mihevc et al., 2021). However, no reliable identification at genus level (log score $\geq 1.7$ ) or species level (log score $\geq 2.0$ ) is possible for Helicobacter species using the latest MALDI database (Berlamont et al., 2021). Indeed, there are currently only two $H$. canis among the 24 Helicobacter entries in the MALDI Biotyper reference database library (Bruker Daltonics). This incompleteness of the mass spectrometry database and the particular culture conditions inducing a degradation of the MALDI-TOF MS fingerprint may lead to an inadequate identification by MALDI-TOF MS (Welker, 2011; Murray, 2012). Sending the organism out to a reference laboratory should therefore be considered in case of a challenging identification.

Molecular methods such as $16 \mathrm{~S}$ rRNA gene sequencing were therefore more reliable for final identification (Shakir et al., 2017). Although the search for $H$. canis in a rich digestive flora could be particularly difficult, it may be relevant to identify the source. Passive filtration over Columbia agar supplemented with 5\% sheep blood agar (CBA) or direct plating on CBA plus cefoperazone, amphotericin B, and teicoplanin has been suggested to isolate the bacteria 
among others (Ochoa et al., 2019). Considering these growing features, $H$. canis is a fastidious germ challenging routine microbiology laboratories. As a result, the detection rate in clinical laboratories is certainly underestimated, and clinicians probably miss bacteremia, hence the importance of sufficient blood volume to increase the detection sensitivity of such a pathogen. Some routine laboratories do not even culture Helicobacter species but may rely on histopathological diagnostic methods or reference laboratories culturing this germ and using molecular methods for identification. A good communication between clinicians and microbiologist is needed in order to optimize sample growth conditions and to choose the most adequate antimicrobial therapy.

As no guidelines were available for AST, we chose to interpret measured MICs with either $H$. pylori or PKPD EUCAST breakpoints (The European Committee on Antimicrobial Susceptibility Testing, 2021). Based on EUCAST recommendations, MIC values were reported and their interpretation was rendered with caution. Many previous reports decided not to perform AST due to fastidious growth and lack of interpretation criteria. Only two cases reported MICs by $E$-test method and those were similar to ours except for clindamycin (0.094 and $12 \mu \mathrm{g} / \mathrm{ml}$, respectively) (Leemann et al., 2006; Mihevc et al., 2021). Low MICs were observed as in our report for penicillins, amoxicillin-clavulanate, carbapenems, and metronidazole. One report obtained a high MIC for piperacillin-tazobactam (1 $\mu \mathrm{g} / \mathrm{mL}$ ) (Leemann et al., 2006). We obtained identical MIC for ceftriaxone $(0.75 \mu \mathrm{g} / \mathrm{ml})$. We furthermore observed low MICs for tetracycline and rifampicin as opposed to another case reporting a high MIC for ciprofloxacin (> $32 \mu \mathrm{g} / \mathrm{ml}$ ). In 2019, although it was performed on a strain isolated from dog stool, a study reported MICs by agar dilution method. The major divergent result in comparison to AST realized on human strains concerned thirdgeneration cephalosporins as MICs were high for cefsulodin and cefoperazone $(128 \mu \mathrm{g} / \mathrm{ml})$. They additionally observed full resistance for glycopeptides and trimethoprim (Ochoa et al., 2019). The germ is commonly found to be resistant to cephalothin with a MIC of $32 \mu \mathrm{g} / \mathrm{ml}$ except in one report (Shen et al., 2001). All studies also observed in vitro susceptibility of the germ for nalidixic acid (Stanley et al., 1993; Fox et al., 1996; Foley et al., 1999; Shen et al., 2001; Prag et al., 2007).

Relevant clinical features of published reports and their relative frequencies are summarized in Table 2 . Its ability to cause bacteremia is highlighted in $83 \%$ of cases, mainly in patients with underlying conditions. Two reports that did not describe bacteremia mentioned the detection of $H$. canis in patients with digestive symptoms, one with gastroenteritis and the other with duodenal ulcerations attributed to Crohn's disease (Burnens et al., 1993; Tankovic et al., 2011). Multiple clinical similarities between most cases were observed such as recurrent fever, immunocompromised status, or comorbidities and close contact with pets. On the other hand, digestive symptoms such as diarrhea were not systematically found, which could potentially explain extra-digestive origin of bacteremia such as the skin. Indeed, plausible skin entry points were described such as cellulitis or as in our case a superficial wound
TABLE 2 | Clinical features of previous and current Helicobacter canis reports.

\begin{tabular}{|c|c|c|}
\hline Variables $^{a}$ & $\begin{array}{l}H . \text { canis reports } \\
\qquad N=12\end{array}$ & $\%$ or Min-max \\
\hline \multicolumn{3}{|l|}{ Demographics } \\
\hline Adults & 9 & 75 \\
\hline Female & 6 & 50 \\
\hline Age (years) & 46.5 & $0.2-78.0$ \\
\hline Underlying conditions in adults $(N=9)$ & 8 & 89 \\
\hline Immunosuppressors & 5 & 56 \\
\hline ESRD & 3 & 33 \\
\hline Splenectomized & 2 & 22 \\
\hline Others $^{b}$ & 5 & 56 \\
\hline \multicolumn{3}{|l|}{ Clinical findings } \\
\hline Fever & 7 & 58 \\
\hline Skin abnormalities & 4 & 33 \\
\hline Digestive symptoms & 4 & 33 \\
\hline \multicolumn{3}{|l|}{ Laboratory findings } \\
\hline Bacteremia & 10 & 83 \\
\hline WBC at hospitalization $\left(\times 10^{9} / \mathrm{L}\right)$ & 10.350 & $7.900-15.000$ \\
\hline CRP at hospitalization (mg/dl) & 7.7 & $0-9.4$ \\
\hline Close contact with pets & $10^{c}$ & 83 \\
\hline Dog & 8 & 67 \\
\hline Cat & 4 & 33 \\
\hline \multicolumn{3}{|l|}{ Management and outcome } \\
\hline Cephalosporin based antibiotherapy & 7 & 58 \\
\hline In-hospital time (days) & 5 & $3-15$ \\
\hline Fatal outcome & $1^{d}$ & 8 \\
\hline
\end{tabular}

a Variables expressed as number of cases reported (\%) or median (minimummaximum observed rank).

${ }^{b}$ Chronic pancreatitis, lymphoma, sarcoidosis, Crohn's disease, or rheumatoid arthritis.

${ }^{c}$ Two cases did not mention the presence or absence of a pet.

${ }^{d}$ One case reported $\mathrm{H}$. canis bacteremia in a 2-month infant with cardiorespiratory arrest. CRP, C-reactive protein; ESRD, End-stage renal disease; WBC, white blood cells.

(Gerrard et al., 2001; Leemann et al., 2006; Shakir et al., 2017). The pathogen was not exclusively found in adults as three cases were observed in children including a bacteremia in a healthy 7 month-old baby (Burnens et al., 1993; Prag et al., 2007; GutiérrezArroyo et al., 2017).

Despite one case reporting the sudden death of a 2-monthold infant with associated $H$. canis bacteremia (GutiérrezArroyo et al., 2017), a positive outcome has been reported in 9 out of 10 bacteremia reports despite the presence of underlying conditions in most cases. This could potentially be explained by the in vitro susceptibility of $H$. canis to several antibiotics, including penicillins. However, it has been suggested that in vitro susceptibility of the pathogen may not correlate with clinical response (Gerrard et al., 2001). Indeed, three authors reported patients that had experienced clinical recurrence after initial treatment with a combination of intravenous ampicillin and gentamicin (Gerrard et al., 2001; Prag et al., 2007) or oral amoxicillin-clavulanate (Leemann et al., 2006). Continued treatment by oral ciprofloxacin or mecillinam also did not prevent recurrence. Another patient received an oral combination of amoxicillin and clarithromycin based on $H$. pylori 
eradication therapy and was cured after 4 weeks (Alon et al., 2010), thereby suggesting that the addition of a macrolide results in a favorable outcome. Initial treatment with oral doxycycline (Abidi et al., 2013; Shakir et al., 2017), intravenous cefuroxime (van der Vusse et al., 2014), and intravenous ceftriaxone as administered in our case report also showed positive outcomes. Switching to intravenous ceftriaxone or a combination of oral doxycycline and metronidazole also provided a clinical cure after an initial treatment failure (Gerrard et al., 2001; Leemann et al., 2006).

\section{CONCLUSION}

To date, clinical cases with $H$. canis are poorly described in the literature and prevalence is most likely underestimated. This is partly due to the difficulty of laboratories to detect, culture, and identify the microorganism given the need for molecular methods. We were nevertheless able to identify microbiological trends concerning the reported bacteremias and particularly the need to consider at least 7 days from blood sampling to identification and even more for obtaining AST. The lack of treatment guidelines and the paucity of data about in vivo and in vitro $H$. canis antimicrobial susceptibility lead clinicians to adopt treatment strategies not guided by susceptibility testing. Here we suggested ceftriaxone, doxycycline, or metronidazole as the best therapeutic choices once the pathogen has been identified. Moreover, this review also identified common clinical features, especially the frequent

\section{REFERENCES}

Abidi, M. Z., Wilhelm, M. P., Neff, J. L., Hughes, J. G., Cunningham, S. A., and Patel, R. (2013). Helicobacter canis bacteremia in a patient with fever of unknown origin: fig 1. J. Clin. Microbiol. 51, 1046-1048. doi: 10.1128/JCM. 02548- 12

Alon, D., Paitan, Y., Ben-Nissan, Y., and Chowers, M. (2010). Persistent Helicobacter canis bacteremia in a patient with gastric lymphoma. Infection 38 , 62-64. doi: 10.1007/s15010-009-9067-6

Berlamont, H., De Witte, C., De Bruyckere, S., Fox, J. G., Backert, S., Smet, A., et al. (2021). Differentiation of gastric Helicobacter species using MALDI-TOF mass spectrometry. Pathogens 10:366. doi: 10.3390/pathogens10030366

Burnens, A. P., Stanley, J., Schaad, U. B., and Nicolet, J. (1993). Novel Campylobacter-like organism resembling Helicobacter fennelliae isolated from a boy with gastroenteritis and from dogs. J. Clin. Microbiol. 31, 1916-1917. doi: 10.1128/JCM.31.7.1916-1917.1993

Ekman, E., Fredriksson, M., and Trowald-Wigh, G. (2013). Helicobacter spp. in the saliva, stomach, duodenum and faeces of colony dogs. Vet. J. 195, 127-129. doi: 10.1016/j.tvjl.2012.05.001

Foley, J. E., Marks, S. L., Munson, L., Melli, A., Dewhirst, F. E., Yu, S., et al. (1999). Isolation of Helicobacter canis from a colony of Bengal cats with endemic diarrhea. J. Clin. Microbiol. 37, 3271-3275. doi: 10.1128/JCM.37.10.3271-3275. 1999

Fox, J. G., Drolet, R., Higgins, R., Messier, S., Yan, L., Coleman, B. E., et al. (1996). Helicobacter canis isolated from a dog liver with multifocal necrotizing hepatitis. J. Clin. Microbiol. 34, 2479-2482. doi: 10.1128/JCM.34.10.2479-2482. 1996

Gerrard, J., Alfredson, D., and Smith, I. (2001). Recurrent bacteremia and multifocal lower limb cellulitis due to Helicobacter-like organisms in a patient with X-linked hypogammaglobulinemia. Clin. Infect. Dis. 33, e116-e118. doi: $10.1086 / 323405$ association of bacteremia in immunocompromised patients with recurrent fever and a close contact with pets, especially dogs. Direct fecal-oral zoonotic transmission prior to bacteremia is therefore potentially the most likely to occur. Finally, this report emphasizes the need for communication between clinicians and microbiologists in order to optimize culture and detection conditions and to adapt a patient's antibiotic therapy as best as possible.

\section{AUTHOR CONTRIBUTIONS}

$\mathrm{BL}$ and $\mathrm{AV}$ analyzed, interpreted, and revised the microbiological data. LB analyzed, interpreted, and revised the clinical data. BL wrote, reviewed, and submitted the manuscript. All authors read and approved the final manuscript.

\section{ACKNOWLEDGMENTS}

We thank the microbiology laboratory technicians for their technical contribution.

\section{SUPPLEMENTARY MATERIAL}

The Supplementary Material for this article can be found online at: https://www.frontiersin.org/articles/10.3389/fmicb. 2021.814944/full\#supplementary-material

Gutiérrez-Arroyo, A., Falces-Romero, I., Corcuera-Pindado, M. T., and RomeroGómez, M. P. (2017). Bacteraemia in a two month-old infant. Enferme. Infecc. Microbiol. Clin. Engl. Ed. 35, 676-677. doi: 10.1016/j.eimce.2017.11.012

Leemann, C., Gambillara, E., Prod'hom, G., Jaton, K., Panizzon, R., Bille, J., et al. (2006). First case of bacteremia and multifocal cellulitis due to Helicobacter canis in an immunocompetent patient. J. Clin. Microbiol. 44, 4598-4600. doi: 10.1128/JCM.01453-06

Liu, J., He, L., Haesebrouck, F., Gong, Y., Flahou, B., Cao, Q., et al. (2015). Prevalence of coinfection with gastric non- Helicobacter pylori Helicobacter (NHPH) species in Helicobacter pylori -infected patients suffering from gastric disease in Beijing, China. Helicobacter 20, 284-290. doi: 10.1111/hel.12201

Ménard, A., Péré-Védrenne, C., Haesebrouck, F., and Flahou, B. (2014). Gastric and enterohepatic Helicobacters other than Helicobacter pylori. Helicobacter 19, 59-67. doi: 10.1111/hel.12162

Mihevc, M., Koren Krajnc, M., Bombek Ihan, M., and Holc, I. (2021). Helicobacter canis bacteraemia in a rheumatoid arthritis patient treated with tofacitinib: case report and literature review. Ann. Clin. Microbiol. Antimicrob. 20:22. doi: 10.1186/s12941-021-00426-x

Momtaz, H., Dabiri, H., Souod, N., and Gholami, M. (2014). Study of Helicobacter pylori genotype status in cows, sheep, goats and human beings. BMC Gastroenterol. 14:61. doi: 10.1186/1471-230X-14-61

Murray, P. R. (2012). What is new in clinical microbiology-microbial identification by MALDI-TOF mass spectrometry. J. Mol. Diagn. 14, 419-423. doi: 10.1016/j.jmoldx.2012.03.007

Ochoa, S., Martínez, O. A., Fernández, H., and Collado, L. (2019). Comparison of media and growth conditions for culturing enterohepatic Helicobacter species. Lett. Appl. Microbiol. 69, 190-197. doi: 10.1111/lam.13192

Ochoa, S., Ojeda, J., Martínez, O. A., Vidal-Veuthey, B., and Collado, L. (2021b). Exploring the role of healthy dogs as hosts of enterohepatic Helicobacter species using cultivation-dependent and -independent approaches. Zoonoses Public Health 68, 344-352. doi: 10.1111/zph.12817 
Ochoa, S., Fernández, F., Devotto, L., France Iglesias, A., and Collado, L. (2021a). Virulence assessment of enterohepatic Helicobacter species carried by dogs using the wax moth larvae Galleria mellonella as infection model. Helicobacter 26:e12808. doi: 10.1111/hel.12808

Prag, J., Blom, J., and Krogfelt, K. A. (2007). Helicobacter canis bacteraemia in a 7-month-old child. FEMS Immunol. Med. Microbiol. 50, 264-267. doi: 10.1111/ j.1574-695X.2007.00271.X

Sabry, M. A., Abdel-Moein, K. A., and Seleem, A. (2016). Evidence of zoonotic transmission of Helicobacter canis between sheep and human contacts. Vector Borne Zoonotic Dis. 16, 650-653. doi: 10.1089/vbz.2016.1994

Shakir, S. M., Powers-Fletcher, M. V., Slechta, E. S., and Fisher, M. A. (2017). Helicobacter canis bacteraemia and cellulitis in a patient with end-stage renal disease. JMM Case Rep. 4:e005126. doi: 10.1099/jmmcr.0.005126

Shen, Z., Feng, Y., Dewhirst, F. E., and Fox, J. G. (2001). Coinfection of enteric Helicobacter spp. and Campylobacter spp. in cats. J. Clin. Microbiol. 39, 21662172. doi: 10.1128/JCM.39.6.2166-2172.2001

Stanley, J., Linton, D., Burnens, A. P., Dewhirst, F. E., Owen, R. J., Porter, A., et al. (1993). Helicobacter canis sp. nov., a new species from dogs: an integrated study of phenotype and genotype. J. Gen. Microbiol. 139, 2495-2504. doi: 10.1099/ 00221287-139-10-2495

Swennes, A. G., Turk, M. L., Trowel, E. M., Cullin, C., Shen, Z., Pang, J., et al. (2014). Helicobacter canis colonization in sheep: a zoonotic link. Helicobacter 19, 65-68. doi: 10.1111/hel.12097

Tabrizi, S., and Atashi, A. (2015). Identification of Helicobacter spp. in gastrointestinal tract, pancreas and hepatobiliary system of stray cats. Iran. J. Vet. Res. 16, 374-376.

Tankovic, J., Smati, M., Lamarque, D., and Delchier, J.-C. (2011). First detection of Helicobacter canis in chronic duodenal ulcerations from a patient with Crohn's disease. Inflamm. Bowel Dis. 17, 1830-1831. doi: 10.1002/ibd.21610
The European Committee on Antimicrobial Susceptibility Testing (2021). Breakpoint Tables for Interpretation of MICs and Zone Diameters, Version 11.0. Available online at: http://www.eucast.org (accessed November 13, 2021).

van der Vusse, M. L., van Son, W. J., Ott, A., and Manson, W. (2014). Helicobacter canis bacteremia in a renal transplant patient. Transpl. Infect. Dis. 16, 125-129. doi: 10.1111/tid.12174

Wauters, G., Avesani, V., Laffineur, K., Charlier, J., Janssens, M., Van Bosterhaut, B., et al. (2003). Brevibacterium lutescens sp. nov., from human and environmental samples. Int. J. Syst. Evol. Microbiol. 53, 1321-1325. doi: 10.1099/ijs.0.02513-0

Welker, M. (2011). Proteomics for routine identification of microorganisms. Proteomics 11, 3143-3153. doi: 10.1002/pmic.201100049

Conflict of Interest: The authors declare that the research was conducted in the absence of any commercial or financial relationships that could be construed as a potential conflict of interest.

Publisher's Note: All claims expressed in this article are solely those of the authors and do not necessarily represent those of their affiliated organizations, or those of the publisher, the editors and the reviewers. Any product that may be evaluated in this article, or claim that may be made by its manufacturer, is not guaranteed or endorsed by the publisher.

Copyright (C) 2022 Lardinois, Belkhir and Verroken. This is an open-access article distributed under the terms of the Creative Commons Attribution License (CC BY). The use, distribution or reproduction in other forums is permitted, provided the original author(s) and the copyright owner(s) are credited and that the original publication in this journal is cited, in accordance with accepted academic practice. No use, distribution or reproduction is permitted which does not comply with these terms. 